\title{
INTERNAL CAUSE ANALYSIS OF DAMAGE OF WOODEN COMPONENTS IN DANXIA TEMPLE ANCIENT ARCHITECTURES: TREE SPECIES
}

\author{
YAN YANG \\ Nanyang Institute Of Technology \\ China \\ He Sun \\ Southwest Forestry University \\ China \\ ShuAng YANG \\ Henan University Minsheng College \\ China \\ Aifeng Wang, Rui Zhao, Wei Wang, Yiming He, Bin Li \\ BinXin Zhang, Qian Wu \\ Nanyang Institute Of Technology \\ China \\ (Received May 2020)
}

\begin{abstract}
In the study, part of degraded wooden components of Danxia Temple ancient architectures in China were indentified through the bright field microscope, and chemical compositions in cell walls were observed using polarized and fluorescence lights, respectively. The results showed that samples were belonged to Quercus spp., Ulmus spp., Salix spp., and Populus spp., respectively. Cellulose composition in Quercus spp. was seriously consumed by brown decay fungi, cellulose and lignin compositions in Ulmus spp. were consumed by white decay fungi under polarized and fluorescence light observations. All of these four kind of tree species themselves were easily vulnerable to be attacked by insects.
\end{abstract}

KEYWORDS: Danxia Temple ancient architectures, wooden components, wood identification, analysis of damage by fungi and insects, polarized light, fluorescence. 


\section{INTRODUCTION}

Danxia Temple, founded in AD 824 and located at Liushan town, Nanzhao county, Nanyang city, Henan province, China, is listed as the national key cultural relic conservation unit. At present, part of the wooden components have been damaged by fungi and insects. Normally, the damage of harmful organisms would cause changes of anatomical structure (Wilcox 1970, Highley et al. 1987, Koyani et al. 2014, Wang et al. 2017, Bari et al. 2019), and degradations of chemical composition (Ferraz et al. 1995, Arias et al. 2010, Witomski et al. 2012, Witomski et al. 2013, Karami et al. 2013, Bari et al. 2019), thereby decrease the quality of its physical and mechanical properties (Ferraz et al. 1995, Choi et al. 2006, Arias et al. 2010, Koyani et al. 2014, Wang et al. 2017, Bari et al. 2019, Li et al. 2019, Brischke et al. 2019, Gao et al. 2019, Chang et al. 2020). These changes eventually decrease the residual mechanical strength of wooden components and affect the quality and life span of ancient architectures. Studying on wood identification and analysis of damage reasons can provide reference and guidance for the future maintenance and reinforcement of the degraded wooden components of the Danxia Temple.

In the present study, the microscopic structures of the wooden components in the Danxia Temple ancient architectures were observed through a bright field microscope to identify the tree species. The extent of damage of these wooden components were observed using polarized light and fluorescence microscopes, respectively. In general, the higher the brightness of the crystalline cellulose birefringence is, the higher the cellulose content is (Zhai et al. 2014, Kanbayashi 2016, Cui et al. 2016b, Yang et al. 2020), and the greater the brightness of green fluorescence intensity is, the higher the lignin density and concentration is (Xu et al. 2009, Yoshizawa et al. 2000, Ma et al. 2011, Wang et al. 2012, Nakagawa et al. 2012, Ma et al. 2013, Cui et al. 2016a,b, Liu et al. 2017a,b, Kiyoto et al. 2018, Yang et al. 2020). Such observations of cellulose and lignin contents and their distributions in the cell walls would provide important data support and theoretical basis for cause analysis of damage, and the maintenance and reinforcement of the Danxia Temple ancient architectures in the future.

\section{MATERIAL AND METHODS}

\section{Materials}

The samples were collected from the wooden components of the Danxia Temple ancient architectures in Nanzhao County, Nanyang City, Henan Province, China. All the wooden component samples, Nos. 3-1, to 3-12, were obtained from the surface of twelve wooden column' roots, respectively. Due to the dark black color of these wooden components, detailed observations of the macroscopic structural characteristics was not possible. Therefore, only the microscopic structural characteristics could be observed and described in detail.

\section{Treatment of the sample}

For air exhausting the small samples were placed into the vacuum dryer to drain the air within the wood samples. For infiltration the samples were immersed into 20\%, 40\%, $60 \%, 80 \%$, and $100 \%$ polyethylene glycol (PEG) aqueous solution successively (molecular weight $=2000$ ). The process was conducted in an oven at $60^{\circ} \mathrm{C}$ for $48 \mathrm{~h}$ every gradient, in which $100 \%$ PEG aqueous solution was infiltrated twice. For PEG embedding the samples were placed at the bottom of the embedding mold. Then, 100\% PEG aqueous solution was added to the samples, and the set-up was covered with a plastic embedding box. The embedding box was placed inside the freezer for about $10 \mathrm{~min}$. 


\section{Sample slicing}

The embedded samples were sliced with microtome (SM2000R, Laika company). Each slice was about $10 \mu \mathrm{m}$ in thickness and included the transverse, radial, and tangential sections. The slices were placed inside a baking machine at $60^{\circ} \mathrm{C}$ for about $60 \mathrm{~min}$ in order to remove the extra water. The slices were dehydrated in 50\%, 75\%, 95\%, and 100\% ethanol solution; each concentration treatment lasted for $10 \mathrm{~min}$. Then the slices were defatted in dimethylbenzene solution for $3 \mathrm{~min}$ and neutral gum was used to seal the slices after all the treatments. To avoid the effect of dye on polarized light and fluorescence, all slices were not dyed with red $\mathrm{O}$ dye.

\section{Observations via bright-field microscopy}

The prepared slices were observed and photographed under a biological digital microscope (ECLIPSE 80i, Nikon Company). To complete the identification of these wood components, their microscopic characteristics were recorded according to the Chinese Timber Records (Cheng et al. 1992) and the IAWA list of microscopic features for hardwood identification (IAWA Committee 1989).

\section{Observation via polarized light and fluorescence microscopy}

The prepared slices were observed and photographed under a polarizing and fluorescent microscope (ECLIPSE 80i, Nikon Company). The cell wall deformations of these wood components was analyzed using a bright-field light microscope. Meanwhile, the cellulose distribution and content in the wooden components were analyzed using a polarized light microscope. The lignin distribution and content in wood components were analyzed using a fluorescence microscope (the blue light excitation with $515 \mathrm{~nm}$ to $560 \mathrm{~nm}$ ) to determine the degree of decay of the wooden components (Cui et al. 2016b).

\section{RESULTS AND DISCUSSION}

\section{Wood identification and analysis of damage of samples Nos. 3-1, 3-2, and 3-6}

Fig. 1 shows the microstructures of sample Nos. 3-1, 3-2, and 3-6. Based on these microstructures, the distribution of vessels with circular and oval circles on the transverse section was that of ring-porous wood, the arrangement of late wood vessels was stream-shape radial pattern, and the combination was mainly exclusively solitary ( $90 \%$ or more). There were almost no or few of tyloses and gums in vessels. The type of perforations was simple perforation plate, and the type of intervessel pits was alternate. No helical thickening of vessels was found throughout the body of vessel elements. Vasicentric tracheids were abundant. An abundance of apotracheal axial parenchymas consisted of diffuse, diffuse-in-aggregates, and narrow bands or lines up to three cells wide with prismatic crystals of more than 15 cells were found. The cell walls of the wood fibers, which were fibrous tracheid with distinctly bordered pits, ranged from thin to thick. Wood rays were non-storied and had rays of two distinct sizes. These rays consisted exclusively of uniseriate rays and larger rays commonly > 10-seriate, the height of which could exceed the range of slices. All ray cells were procumbent cells, and no special cells were found in ray cells. Moreover, no axial and radial intercellular canals was found in these woods. These findings were in good agreement with the microstructures of red oak presented by Yang et al. (2020).

On the basis of the microstructure observations (Figs. 1a,b,c), we concluded that sample Nos. 3-1, 3-2, and 3-6 belonged to red oak wood (Quercus spp.) (Fagaceae) (Cheng et al. 1992). 


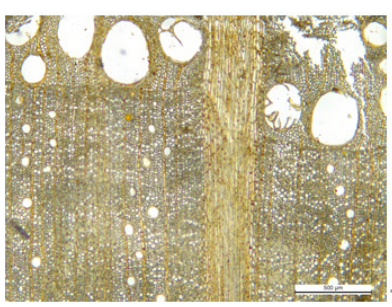

(a) Transverse section (4x).

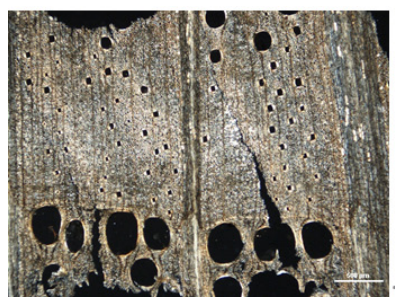

(d) Transverse section (4x).

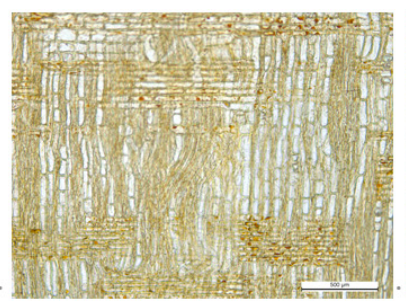

(b) Radial section (4x).

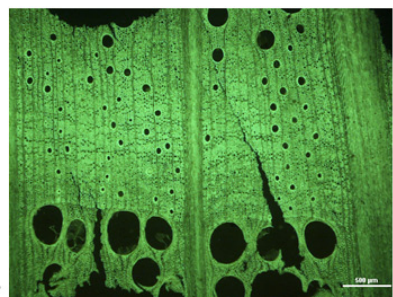

(e) Transverse section (4x).

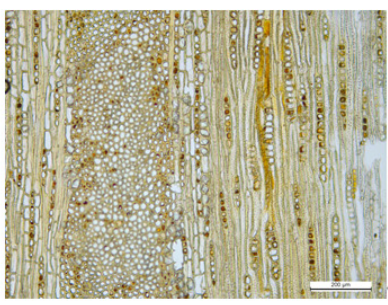

(c) Tangential section $(4 \mathrm{x})$.

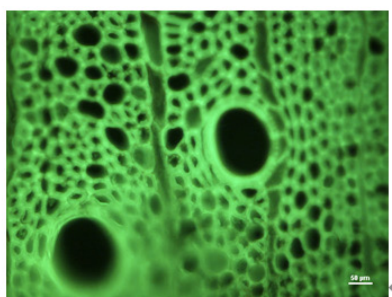

(f) Transverse section (40x).

Fig. 1: Microstructures of sample Nos. 3-1, 3-2 and 3-6: (a),(b),(c) under bright-field light, (d) under polarized light, $(e)$ and $(f)$ under fluorescence light.

Red oak woods have many excellent characteristics, such as, straight grain, heavy basic density (about $0.70 \mathrm{~g} . \mathrm{cm}^{-3}$ ), high hard, strength and impact toughness, but contain high shrinkage, and low resistance to decay fungi compared to white oak wood (Cheng et al. 1992). Under polarized light (Fig. 1d), the brightness of crystalline cellulose birefringence of vessel and wood fiber cell walls was almost not observed both in the early wood and the late wood, indicating that the cellulose composition was severely consumed by decay fungi. Under fluorescence light (Figs. 1e,f), the brightness of fluorescence of vessel and wood fiber cell walls was evident both in early wood and late wood, indicating an abundant amount of lignin composition retained in vessels and wood fibers. Moreover, the fluorescence in the micro-area distribution of lignins was still stronger in the cell corner layer (CC layer) than that in the compound middle lamellar layer (CML layer) and the secondary wall layer (S layer) of fiber cell walls (Fig. 1f). This finding is consistent with the micro-area distribution of lignin in other researches (Yoshizawa et al. 2000, Xu et al. 2009, Ma et al. 2011, Nakagawa et al. 2012, Wang et al. 2012, Ma et al. 2013, Cui et al. 2016a, Liu et al. 2017a, Liu et al. 2017b, Kiyoto et al. 2018). According to the observations, we speculated that cellulose composition was seriously consumed by brown decay fungi which they preferred to assume cellulose composition and retain lignin composition (Guo et al. 2015).

One of the important reasons for the serious decay of red oak wooden components is closely related to the lack of protection of tyloses in vessels. Due to the existence of an abundant of tyloses in white oak woods, these woods have excellent anti-decay, anti-insect, and water resistance properties (Cheng et al. 1992) and are often used as red wine barrel, architecture, and furniture materials. In comparison, red oak woods are not used in these aspects. In addition to vulnerability to decay fungi, red oak woods are especially vulnerable to be attacked by insects, such as domestic longhorn beetles (Stromatium longicorne) (Cerambycidae) and powder-pest beetle (Minthea rugicollis) (Lyctidae) etc. (Cheng et al. 1992). However, almost no difference has been found in their macro-and micro-structures except for tylose between red oak and white 
oak woods. Thus, the ancient architects of Nanyang could not provide an accurate distinction when selecting materials to be used in Danxia Temple ancient architectures, thus leading to the serious decay and damage by insects several years later.

\section{Wood identification and analysis of damage of samples Nos. 3-4, and 3-9}

Fig. 2 shows the microstructures of sample Nos. 3-4, and 3-9 of the wooden components. As shown in these microstructures, the distribution of vessels was that of ring-porous wood. Early vessels with one to three cells of width were circular, oval circle, and orbicular-ovate on the transverse section, and tyloses were contained in many vessels. The arrangement of late vessels was tangential wary bands, and the combinations were mainly clusters common, and a few of exclusively solitary and radial multiples. The type of perforations was simple perforation plate, and the type of intervessel pits was alternate. Helical thickening of late vessels was found throughout the body of vessel elements. Many paratracheal axial parenchymas were found, and these were vasicentric, diffuse-in-aggregates, and wavy banded parenchyma that were more than three cells of width. Wood rays with 2-6 cells of width were non-storied, All ray cells were procumbent cells, and no special cells were found in ray cells. Moreover, no axial and radial intercellular canals was found in these woods.

On the basis of the microstructure observations (Figs. 2a,b,c), we concluded that sample Nos. 3-4, and 3-9 belonged to elm wood (Ulmus spp.) (Ulmaceae) (Cheng et al. 1992).

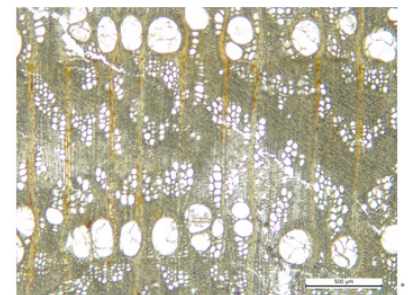

(a) Transverse section $(4 \mathrm{x})$.

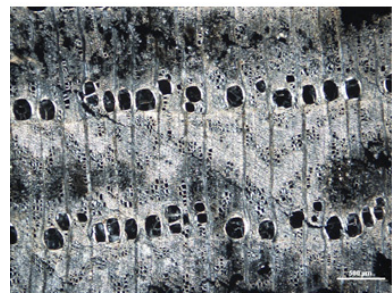

(d) Transverse section (4x).

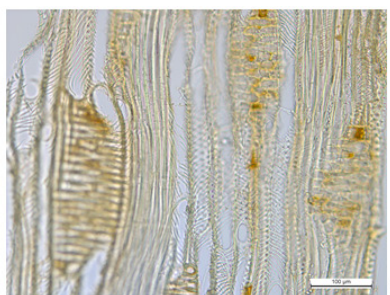

(b) Radial section (20x).

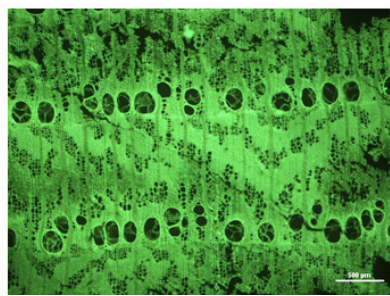

(e) Transverse section (4x).

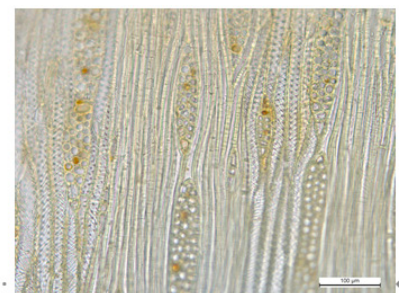

(c) Tangential section $(20 \mathrm{x})$.

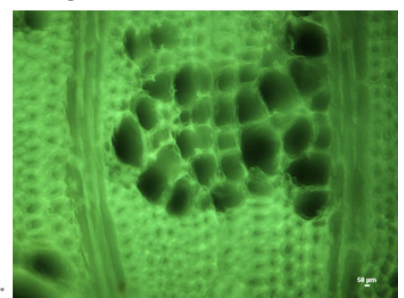

(f) Transverse section (40x).

Fig. 2: Microstructures of sample No. 3-4, and 3-9: (a),(b),(c) under bright-field light, (d) under polarized light, (e) and (f) under fluorescence light.

Elm woods have many excellent characteristics, such as, straight grain, medium structure, medium shrinkage, beautiful pattern, but contain low basic density (about $0.45 \mathrm{~g} \cdot \mathrm{cm}^{-3}$ ), low strength, easy to crack, and low resistance to decay fungi and insects (Cheng et al. 1992). Under polarized light (Fig. 2d), the brightness of crystalline cellulose birefringence of vessel and wood fiber cell walls was evidently observed except for that in part of late wood fibers, indicating that part of cellulose composition were consumed by decay fungi. Under fluorescence light (Figs. 2e,f), the brightness of fluorescence in part of wood fiber cell walls was also not evident, indicating that part of lignin composition was consumed. Moreover, the fluorescence 
in the micro-area distribution of lignins was still stronger in the $\mathrm{CC}$ layer than that in the CML layer and the S layer of fiber cell walls (Fig. 2f). This finding is consistent with the micro-area distribution of lignin in red oak wood in this research and in other researches (Yoshizawa et al. 2000, Xu et al. 2009, Ma et al. 2011, Nakagawa et al. 2012, Wang et al. 2012, Ma et al. 2013, Cui et al. 2016 a, Liu et al. 2017 a, Liu et al. 2017b, Kiyoto et al. 2018). According to the observations, we speculated that cellulose and lignin compositions were consumed by white decay fungi which they consumed not only cellulose and hemicellulose compositions but also lignin composition (Guo et al. 2015).

Elm woods are suitable for furniture due to beautiful pattern. Because elms are native tree species, taking into account the principle of proximity, they were widely used in ancient architectures by ancient architects of Nanyang city. The property of low resistance to decay fungi and insects leaded to the serious damage after several years later

\section{Wood identification and analysis of damage of samples Nos. 3-3, 3-7, 3-8, and 3-12}

Fig. 3 shows the microstructures of sample Nos. 3-3, 3-7, 3-8, and 3-12 of the wooden components. As shown in these microstructures, the distribution of vessels with orbicularovate and oval circle on the transverse section was that of diffuse-porous wood, whereas the arrangement of vessels was diffuse. Furthermore, the combinations of vessels were mainly exclusively solitary and a few of radial multiples of two to four cells. No tyloses and gums were found in the vessels. No helical thickening of vessels was found throughout the body of vessel elements. The type of perforation was simple perforation plate. The type of intervessel pits was alternate. A few of marginal and diffuse-in-aggregates axial parenchymas were found. The cell walls of wood fibers with distinctly simple pits were thin. Wood rays were non-storied, ray cells with one cell of width was upright and procumbent. No special cells and gums were found in the ray cells. No axial and radial intercellular canal was found in these woods.

On the basis of the microstructure observations (Figs. 3a,b,c), we concluded that sample Nos. 3-3, 3-7, 3-8, and 3-12 belonged to willow wood (Salix spp.) (Salicaceae) (Cheng et al. 1992).

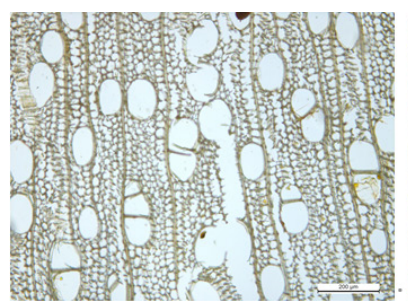

(a) Transverse section (10x).

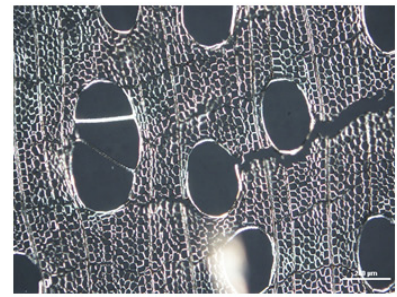

(d) Transverse section (20x).

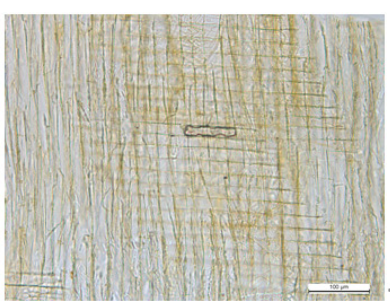

(b) Radial section (20x).

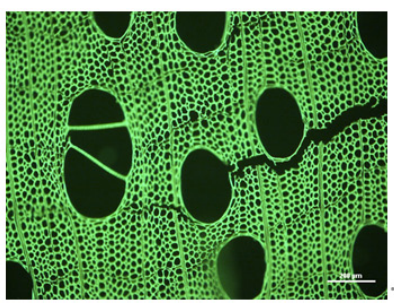

(e) Transverse section (20x).

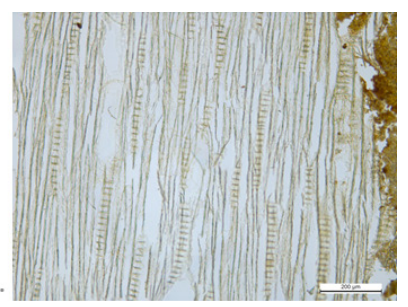

(c) Tangential section (10x).

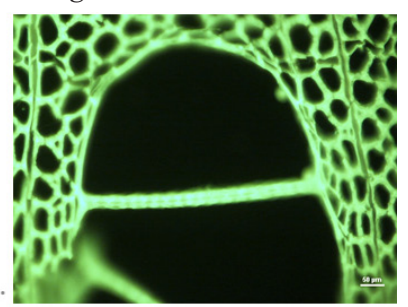

(f) Transverse section (40x).

Fig. 3: Microstructures of sample No. 3-3, 3-7, 3-8, and 3-12: (a),(b),(c) under bright-field light, (d) under polarized light, $(e)$ and $(f)$ under fluorescence light. 
Willows grow fast, and are highly absorbent. The living standing willows are not resistant to decay fungi and insects, so hollow phenomenon occur common. The willow woods have many excellent characteristics, such as, straight grain, fine and smooth structure, low shrinkage, but contain low basic density (about $0.40 \mathrm{~g}^{\mathrm{cm}}-3$ ) and strength, low resistance to decay fungi and insects (Cheng et al. 1992). Under polarized light (Fig. 3d), the brightness of crystalline cellulose birefringence of vessel and wood fiber cell walls was evidently observed, indicating that the cellulose composition still retained in vessels and wood fibers. Under fluorescence light (Figs. 3e,f), the brightness of fluorescence of the cell walls of vessels and wood fibers was also evident, indicating that an abundant of lignin composition existed in vessels and wood fibers. Moreover, the fluorescence in the micro-area distribution of lignins was still stronger in the CC layer than that in the CML layer and the S layer of fiber cell walls. This finding is consistent with the micro-area distribution of lignin in red oak and elm woods in this research and in other researches (Yoshizawa et al. 2000, Xu et al. 2009, Ma et al. 2011, Nakagawa et al. 2012, Wang et al. 2012, Ma et al. 2013, Cui et al. 2016a, Liu et al. 2017a,b, Kiyoto et al. 2018). According to the observation, we speculated that cellulose and lignin compositions were not consumed by decay fungi.

Because willows are native tree species, taking into account the principle of proximity, they were widely used in ancient architectures by the ancient architects of Nanyang city. The property of low resistance to insects was an important internal cause of serious damage.

\section{Wood identification and analysis of damage of samples Nos. 3-5, 3-10, and 3-11}

Fig. 4 shows the microstructures of sample Nos. 3-5, 3-10, and 3-11 of the wooden components. As shown in these microstructures, the distribution of vessels with orbicular-ovate and oval circle on the transverse section was that of diffuse-porous wood or semi-ring-porous, whereas the arrangement of vessels was radial pattern. Furthermore, the combinations of vessels were mainly radial multiples of two to four cells and a few of solitary. No tyloses and gums were found in the vessels. No helical thickening of vessels was found throughout the body of vessel elements. The type of perforation was simple perforation plate. The type of intervessel pits was alternate. A few of marginal and diffuse-in-aggregates axial parenchymas were found. The cell walls of wood fibers with distinctly simple pits was thin. Wood rays were non-storied, all ray cells was procumbent and one cell of width. No special cells and gums were found in the ray cells. No axial and radial intercellular canal was found in these woods.

On the basis of the microstructure observations (Figs. 4 a,b,c), we concluded that sample Nos. 3-5, 3-10, and 3-11 belonged to poplar wood (Populus spp.) (Salicaceae) (Cheng et al. 1992).

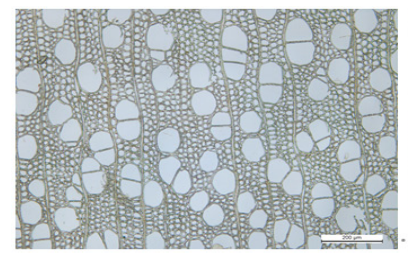

a) Transverse section (10x).

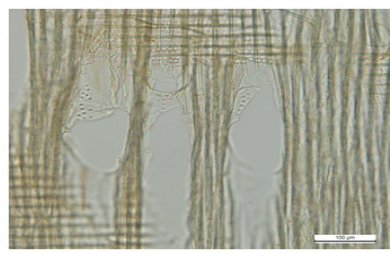

(b) Radial section (20x).

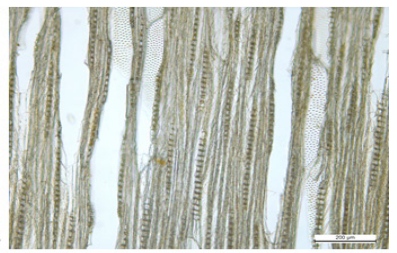

(c) Tangential section (10x). 


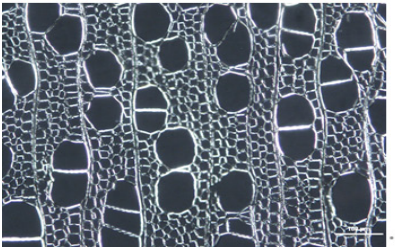

d) Transverse section (20x).

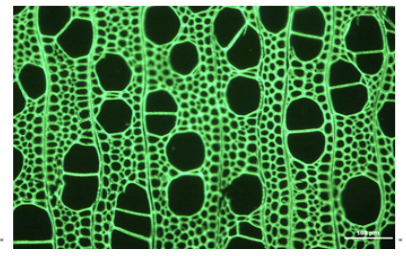

(e) Transverse section (20x).

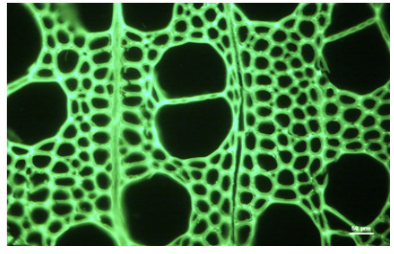

(f) Transverse section (40x).

Fig. 4: Microstructures of sample No. 3-5, 3-10, and 3-11: (a),(b),(c) under bright-field light, (d) under polarized light, (e) and ( $f$ ) under fluorescence light.

Poplars grow fast, the moisture content of raw woods are quite high, the wet heartwood phenomena are especially obvious almost in all poplar trees. And the living standing poplars are not resistant to decay fungi and insects. Especially in spring, we can always hear woodpeckers pecking at insects on poplar trees. The poplar woods have many excellent characteristics, such as, straight grain, fine and smooth structure, low shrinkage, but contain low basic density (about $0.35 \mathrm{~g} \cdot \mathrm{cm}^{-3}$ ), low strength and impact toughness, and low resistance to decay fungi and insects (Cheng et al. 1992). Under polarized light (Fig. 4d), the brightness of crystalline cellulose birefringence of vessel and wood fiber cell walls was evidently observed, indicating that the cellulose composition still retained in vessels and wood fibers. Under fluorescence light (Figs. 4e,f), the brightness of fluorescence of vessel and wood fiber the cell walls of was also evident, indicating that an abundant of lignin composition existed in vessels and wood fibers. Moreover, the fluorescence in the micro-area distribution of lignins was still stronger in the CC layer than that in the CML layer and the S layer of fiber cell walls. This finding is consistent with the micro-area distribution of lignin in red oak, elm and willow woods in this research and in other researches (Yoshizawa et al. 2000, Xu et al. 2009, Ma et al. 2011, Nakagawa et al. 2012, Wang et al. 2012, Ma et al. 2013, Cui et al. 2016a, Liu et al. 2017a,b, Kiyoto et al. 2018). According to the observation, we speculated that cellulose and lignin compositions were not consumed by decay fungi. Poplar woods are suitable for pulp, fibreboard, particleboard, packing box, toothpick and so on, but not suitable for buildings. Because poplars are native tree species, taking into account the principle of proximity, they were widely used in ancient buildings by the ancient architects of Nanyang city. The property of low resistance to insects resulted in the serious damage after several years later.

Different tree species have different ability to resist decay, some have high ability to resist decay such as, white oak woods, softwoods, etc.; others are low, such as, red oak, elm, willow, poplar woods in this paper. In addition to vulnerability to decay fungi and insects themselves, an important reason might be that these wooden components did not be treated with preservative and insect-resist agents prior to use, thus leading to the serious decay and damage by insects several years later.

\section{CONCLUSIONS}

Sample Nos. 1-12 from the wood components of the Danxia Temple ancient architecture were identified and the reason of damage by fungi and insects were analysed. The conclusions are as follows: (1) On the basis of the microstructure observations, we concluded that sample Nos. 3-1, 3-2, and 3-6 belonged to Quercus spp. According to the observations under polarized 
light and fluorescence light, we speculated that the cellulose composition was seriously consumed by brown decay fungi. In additional, red oak woods themselves are easily vulnerable to be attacked by insects. (2) On the basis of the microstructure observations, we concluded that sample Nos. 3-4, and 3-9 belonged to Ulmus spp. According to the observations under polarized light and fluorescence light, we speculated that cellulose and lignin compositions were consumed by white decay fungi. In additional, elm woods themselves are easily vulnerable to be attacked by insects. (3) On the basis of the microstructure observations, we concluded that sample Nos. 3-3, 3-7, 3-8, and 3-12 belonged to Salix spp. According to the observations under polarized light and fluorescence light, we speculated that cellulose and lignin compositions were not consumed by decay fungi, but were attacted by insects due to its themselves vulnerability to insects. (4) On the basis of the microstructure observations, we concluded that sample Nos. 3-5, 3-10, and 3-11 belonged to Populus spp. According to the observations under polarized light and fluorescence light, we speculated that cellulose and lignin compositions were not consumed by decay fungi, but were attacted by insects due to Willow woods themselves are easily vulnerable to be attacked by insects due to its themselves vulnerability to insects

\section{ACKNOWLEDGMENT}

The authors gratefully acknowledge financial supports from Natural National Science Foundation of China (31700481), Cross-science Research Project of Nanyang Institute of Technology, Scientific Research Start-up Projects of Nanyang Institute of Technology, and Humanities and Social Sciences Research Project of Henan Province (2021-ZZJH-252).

\section{REFERENCES}

1. Arias, M.E., Rodríguez, J., Pérez, M.I., Hernández, M., Polvillo, O., González-Pérez, J.A., González-Vila, F.J., 2010: Analysis of chemical changes in Picea abies wood decayed by different Streptomyces strains showing evidence for biopulping procedures. Wood Science and Technology 44(2): 179-188.

2. Bari, E., Daryaei, M.G., Karim, M., Bahmani, M., Schmidt, O., Woodward, S., Ghanbary, M.A.T., Sistani, A., 2019: Decay of Carpinus betulus wood by Trametes versicolor An anatomical and chemical study. International Biodeterioration and Biodegradation 137: 68-77.

3. Brischke, C., Stricker, S., Meyer-Veltrup, L., Emmerich, L., 2019: Changes in sorption and electrical properties of wood caused by fungal decay. Holzforschung 73(5): 445-455.

4. Chang, L., Rong, B.M., Xu, G., Meng, Q. Wang, L., 2020: Mechanical properties, components and decay resistance of Populus davidiana bioincised by Coriolus versicolor. Journal of Forestry Research 31: 2023-2029.

5. Cheng, J.Q., Yang, J.J., Liu, P., 1992:, China Forestry Publishing House. Chinese timber records. Pp 295, 577, 583, and 688.

6. Choi, J.W., Choi, D.H., Ahn, S.H., Lee, S.S., Kim, M.K., Meier, D., Faix, O., Scott, G.M., 2006: Characterization of trembling aspen wood (Populus tremuloides L.) degraded with the white rot fungus Ceriporiopsis subvermispora and MWLs isolated thereof. Holz als Roh- und Werkstoff 64(5): 415-422.

7. Cui, H.S., Yang, S.M., Liu, X.E., Ma, J.F., Tian, G.L., 2016a: Chemical composition and lignin distribution of Salix integra. Chemistry and Industry of Forest Products 36(5): $120-126$.

8. Cui, X.J., Qiu, J., Gao, J.R., 2016b: Evaluation of the decay level and reinforcement of 
ancient wood by fluorescence and polarizing technology. Sciences Of Conservation And Archaeology 28(4): 48-53.

9. Ferraz, A., Durán, N., 1995: Lignin degradation during softwood decaying by the ascomycete Chrysonilia sitophila. Biodegradation 6(4): 265-274.

10. Gao, S., Yue, X.Q. Wang, L.H., 2019: Effect of the degree of decay on the electrical resistance of wood degraded by brown-rot fungi. Canadian Journal of Forest Research 49: 145-153.

11. Guo, M.L., Lan, H.F., Qiu, J., 2015: Wood deterioration and preservation. China Metrology Publishing House. Beijing, Pp 167-168.

12. Highley, T.L., Murmanis, L.L., 1987: Micromorphology of degradation in Western hemlock and sweetgum by the white-rot fungus Coriolus versicolor. Holzforschung 41(2): 67-71.

13. IAWA Committee. 1989: IAWA list of microscopic features for hardwood identification. IAWA Bull. Leiden, 226 pp.

14. Kanbayashi, T., Miyafuji, H., 2016: Effect of ionic liquid treatment on the ultrastructural and topochemical features of compression wood in Japanese cedar (Cryptomeria japonica). Scientific Reports 6: 1-8.

15. Karami, L., Schmidt, O., Fromm, J., Klinberg, A., Schmitt, U., 2013: Wood decay characterization of a naturally-infected oak wood bridge using PY-GC/MS. Wood Research 58(4): 591-598.

16. Kiyoto, S., Yoshinaga, A., Fernandez-Tendero, E., Day, A., Chabbert, B., Takabe, K., 2018: Distribution of lignin, hemicellulose, and arabinogalactan protein in hemp phloem fibers. Microscopical Society of Canada 24(4): 442-452.

17. Koyani, R.D., Rajput, K.S., 2014: Light microscopic analysis of Tectona grandis L.f. wood inoculated with Irpex lacteus and Phanerochaete chrysosporium. European Journal of Wood and Wood Products 72(2): 157-164.

18. Li, S., Gao, Y., Brunetti, M., Macchioni, N., Nocetti, M., Palanti, S., 2019: Mechanical and physical properties of Cunninghamia lanceolata wood decayed by brown rot. Forest 12: 317-322.

19. Liu, C.W., Su, M.L., Zhou, X.W., Zhao, R.J., Lu, J.X., Wang, Y.R., 2017a: Analysis of content and distribution of lignin in cell wall of transgenic poplar with fourier infrared spectrun (FTIR) and confocal laser scanning microscopy (CLSM). Spectroscopy and Spectral Analysis 37(11): 3404-3408.

20. Liu, X.E., Jin, K.X., Cui, H.S., Ma, J.F., 2017b: The lignin topochemistry of Daemonorops margaritae (Hance) Becc. by molecular spectroscopic imaging. Spectroscopy and Spectral Analysis 37(10): 3138-3144.

21. Ma, J.F., Ji, Z., Zhou, X., Zhang, Z.H., Xu, F., 2013: Transmission electron microscopy, fluorescence microscopy, and confocal raman microscopic analysis of ultrastructural and compositional heterogeneity of Cornus alba L, wood cell wall. Microscopy and Microanalysis 19(1): 243-253.

22. Ma, J.F., Yang, G.H., Mao, J.Z., Xu, F., 2011: Characterization of anatomy, ultrastructure and lignin microdistribution in Forsythia suspensa. Industrial Crops and Products 33(2): 358-363.

23. Nakagawa, K., Yoshinaga, A., Takabe, K., 2012: Anatomy and lignin distribution in reaction phloem fibres of several Japanese hardwoods. Annals of Botany 110(4): 897-904.

24. Wang, D., Peng, L.M., Fu, F., Song, B.Q. Liu, M.H., 2017: Changes of microscopic structures and sound absorption properties of decayed wood. Wood Research 62(4): 529-538.

25. Wang, Y.R., Xing, X.T., Ren, H.Q., Yu, Y., Fei, B.H., 2012: Distribution of lignin 
in Chinese fir branches determined microspectrometer ultraviolet. Spectroscopy and Spectral Analysis 32(6): 1685-1688.

26. Wilcox, W.W., 1970: Anatomical changes in wood cell walls attacked by fungi and bacteria. Botanical Review 36(1): 1-28.

27. Witomski, P., Radomski, A., Zawadzki, J., Tomaszewski, W., 2013: Variation in cellulose properties in the common pine (Pinus sylvestris L.) wood during white- and brown-rot decay induced by Coniophora puteana and Trametes versicolor fungi. Wood Research 58(2): 165-172.

28. Witomski, P., Zawadzki J., Radomski A., 2012: Changes of the pine wood (Pinus sylvestris L.) chemical composition during white- and brown-rot decay originated from chosenfungi species. Wood Research 57(3): 463-468.

29. Xu, F., Mao, J.Z., Jones, G.L., Sun, R.C., 2009: Ultrastructure and lignin distribution in fiber cell walls of Caragana korshinskii normal wood and tension wood. Transactions of china pulp and paper 24(4): 15-18.

30. Yang, Y., Sun, H., Li, B., Han, L., Wang, A.F., Wang, W., He, Y.M., Zhao, R. 2020: Study on the identification and the extent of decay of the wooden components in the Xichuan Guild Hall ancient architectures. International Journal of Architectural Heritage 6: 1-10.

31. Yang, Y., He, Y.M., Han, L., Wang, A.F., Wang, W., Zhao, R., Li, B., 2020: Application of histochemical stains for rapid qualitative analysis of the lignin content in multiple wood species. BioResources 15(2): 3524-3533.

32. Yoshizawa, N., Inami, A., Miyake, S., Ishiguri, F., Yokota, S., 2000: Anatomy and lignin distribution of reaction wood in two Magnolia species. Wood Science and Technology 34(3): 183-196.

33. Zhai, S.C., Horikawa, Y., Imai, T., Sugiyama, J., 2014: Cell wall ultrastructure of palm leaf fibers. IAWA Journal 35(2): 127-137.

\author{
YAN YANG* \\ Nanyang Institute Of Technology \\ 1School Of Architecture \\ ${ }^{2}$ Henan Key Laboratory Of Zhang Zhonguing Formulae \\ And Herbs For Immunoregulation \\ Changjiang Road 8o\#, Wancheng District \\ NANYANG \\ China \\ *Corresponding author: yangyanrainy@163.com
}

He Sun

Southwest Forestry University

College Of Material Science

And Engineering

Bailong Road 300\#, Panglong District

KunMing

China 
ShuAng Yang

Henan University Minsheng College

School Of Economics

Jinmin Street, Longting District

KAIFENG

China

Aifeng Wang, Rui Zhao, Wei Wang, Yiming He, Bin Li,

BinXin Zhang, Qian Wu

Nanyang Institute Of Technology

School Of Architecture

Changuiang Road 8o\#, Wancheng District

NANYANG

CHINA 